\title{
Assessing impact of changes in human resources features on enterprise activities: simulation model
}

\author{
Svetlana Kalmykova ${ }^{1,}$, Alexander Krasnoshchekov ${ }^{1}$, and Tatyana Gileva ${ }^{2}$ \\ ${ }^{1}$ Peter the Great St. Petersburg Polytechnic University, 195251 St.Petersburg, Russia \\ ${ }^{2}$ Ufa State Aviation Technical University, 450008 Ufa, Russia
}

\begin{abstract}
The need for creating programs of human resources development is shown; the impact of these programs on organizational effectiveness is taken into account. The stages of development tools and HRD programs on the basis of cognitive modelling are disclosed; these stages will help assess the impact of HR-practices on the key indicators of organization activity at the design stage. The method of HR-practices'pre-selection in professional development of the employees is represented.
\end{abstract}

\section{Introduction}

To solve the problem of assessing the impact of changes in the characteristics of human resources in the performance of the enterprise the dynamic simulation modeling environment PowerSim Studio 7 was selected; this environment has the following advantages: there is room for solving optimization problems; advanced tools for presentation of graphs and reports; user-friendly interface. Models built with the help of PowerSim Studio, are dynamic: they make it possible not only to investigate the structure of the system, but also to get the forecast for the development by simulating its behavior over in time. The structure of the model, built according to the investigated enterprise is shown in Fig. 1.

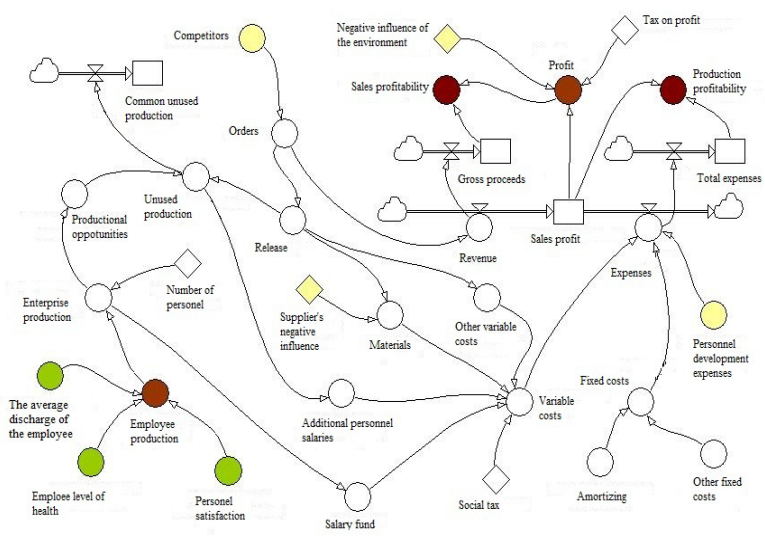

Fig. 1. The structure of the simulation model of the impact human evaluation resources on the economic results of the enterprise.

As the enterprise is an open system, it is a subject of external factors' impact, we introduced constants and variables that reflect the influence of these factors to the simulation model for the realization of the situational approach. For example, the constant "negative influence of the environment" reflects the possibility of negative charges, which affect the value of profit on sales (nonpayment of a receivable, penalties and interest on overdue accounts payable, etc.). The constant "suppliers' negative influence" shows the influence of raw material suppliers (increase in raw material prices, the change of the supplier). Variable "competitors" was introduced to take into account, in particular, possible changes in the scope of the enterprise orders, which can be caused by a decrease in the prices of competitors, the entry of new manufacturers of similar products, and others. PowerSim Studio allows alternative calculations using the controls, which are the following human resources indicators for this model: "The average discharge of the employee» (X1), «The employer's level of health» (X2) and "coefficient of staff satisfaction» (X3). Using controls, you can change the values of variables and see how to change the behavior of the model.

\section{Selecting HR-practices}

We shall dwell on the employee satisfaction in more detail, because the results of the correlation analysis (Table 1) show that this factor have the greatest impact on productivity. The indicators that got the lowest value in the satisfaction questionnaire are: opportunities for professional development (9 persons); social security from the enterprise (7 persons); the level of stress at work (6 people). We can assume that if we do not carry out any changes to improve these indicators, there is a high probability that these people will leave the enterprise in the near future. The dismissal of these workers will be reflected in the coefficient of employee satisfaction. Possible values of this coefficient, calculated on the basis of the total headcount of the

\footnotetext{
Corresponding author: kalmykovas@mail.ru
} 
analyzed unit, at different developments are presented in Table 1.

Table 1. Possible values of the employee satisfaction coefficient $\left(X_{3}\right)$.

\begin{tabular}{|l|c|}
\hline Case & $\begin{array}{l}\text { Values of the employee } \\
\text { satisfaction coefficient }\end{array}$ \\
\hline No one is dismissed & 1 \\
\hline $\begin{array}{l}9 \text { people stay, 7+6 people are } \\
\text { dismissed }\end{array}$ & 0,87 \\
\hline $\begin{array}{l}7 \text { people stay, 9+6 people are } \\
\text { dismissed }\end{array}$ & 0,75 \\
\hline $\begin{array}{l}\text { 6 people stay, 9+7 people are } \\
\text { dismissed }\end{array}$ & 0,67 \\
\hline All 22 people are dismissed & 0,52 \\
\hline
\end{tabular}

Alternatively when no one is dismissed is possible in case of the implementation of positive changes for all three employees dedicated dissatisfaction factors. Alternatively, when 9 people remain and 13are dismissed is possible when a great opportunity for professional development exists. Alternatively when 7 people remain, and 15 are dismissed is possible if the improvements are implemented only in social security part of the enterprise. Alternatively when 6 people stay and 16 are dismissed is possible if the level of stress at work is reducing and the other two directions stay in constant conditions. Finally, if improvement is realized option, all 22 discontented man will be dismissed.

As the issues related to the increase of professional qualifications on the one hand, are the most significant cause of the enterprise's employees' dissatisfaction, and, on the other, they determine the competitiveness of goods and services of the enterprise it was decided to start a program of employees' professional development. It should be noted that the results of analysis on the private enterprise are consistent with the conclusions of the research [10] in defining the relationship between human resource management and efficiency of Russian companies. This research showed that the most important from the standpoint of organizational efficiency for the companies is the practice of training.

For the formation of a professional development program it has been proposed a technique based on the analysis of employee position competencies profiles and, as well as the systematization of the most common forms and training methods. [1] This method includes two enlarged steps:

- Identification of competence development needs;

- The selection of teaching methods (competency development).

In the first phase:

- By expert evaluation in the framework developed by the enterprise competency models for a 5-point scale specified degree of each competency importance for the task (IL);

- The certification of employees for compliance with competency model their positions is carried out; assessment result is staff level (EL), from 1 to 5 points;
- For the evaluated employee the degree of development problematical character for each competence profile is determined ( $\mathrm{PC}=5$ - EL);

- The highest priority for the development of competence are determined (the sum of IS and EL); competencies ranking matrix is formed on the criteria of "degree of importance" - "the degree of problem".

Explanation and results and of competence assessment for marketing department specialist of the enterprise are shown in Table 2. Priority development requires competence $\mathrm{C} 3, \mathrm{C} 9$ and $\mathrm{C} 13$. This situation is largely determined because the employee has recently started to work in the company, where he came from the outside.

Table 2. Evaluation of professional competence of the enterprise marketing department.

\begin{tabular}{|c|c|c|c|c|c|}
\hline $\begin{array}{l}\text { Group of } \\
\text { competenc } \\
\text { es }\end{array}$ & Competence & EL & IL & $\begin{array}{l}\mathbf{P} \\
\mathbf{C}\end{array}$ & $\begin{array}{l}\text { Priorit } \\
\mathbf{y}\end{array}$ \\
\hline Functional & $\begin{array}{l}\text { 1. Education } \\
\text { 2. Working experience } \\
\text { 3. Knowledge of market } \\
\text { 4. Sales technique } \\
\text { 5. Problem solvation }\end{array}$ & $\begin{array}{l}3 \\
3 \\
2 \\
4 \\
3\end{array}$ & $\begin{array}{l}4.3 \\
3.7 \\
4.7 \\
4.3 \\
3.3\end{array}$ & $\begin{array}{l}2 \\
2 \\
3 \\
1 \\
2\end{array}$ & $\begin{array}{l}6.3 \\
5.7 \\
7.7 \\
5.3 \\
5.3\end{array}$ \\
\hline Cognitivee & $\begin{array}{l}\text { 6. System approach } \\
\text { knowledge } \\
\text { 7. Marketing } \\
\text { knowledge } \\
\text { 8. Knowledge of } \\
\text { economy } \\
9 . \text { Knowledge of } \\
\text { technical and design } \\
\text { features of enterprise's } \\
\text { production }\end{array}$ & $\begin{array}{l}2 \\
4 \\
3 \\
2\end{array}$ & $\begin{array}{l}2.3 \\
4.3 \\
3.3 \\
3.7\end{array}$ & $\begin{array}{l}3 \\
2 \\
2\end{array}$ & $\begin{array}{l}5.3 \\
7.3 \\
5.3 \\
6.7\end{array}$ \\
\hline Personal & $\begin{array}{l}\text { 10. Communicativeness } \\
\text { 11. Team work } \\
\text { 12 Collaboration } \\
\text { 13. Understanding of } \\
\text { the company's values } \\
\text { 14. Development } \\
\text { orientation }\end{array}$ & $\begin{array}{l}4 \\
3 \\
4 \\
3\end{array}$ & $\begin{array}{l}3.3 \\
3.7 \\
4.3 \\
5.0\end{array}$ & $\begin{array}{l}1 \\
2\end{array}$ & $\begin{array}{l}4.3 \\
5.7 \\
5.3 \\
7.0\end{array}$ \\
\hline
\end{tabular}

At the second stage, the teaching methods are selected (competency development). Previously, as a result of generalization of experience $[5,15,16,19,27]$, a list of the 16 HR-practices in the field of professional development of employees was compiled and their systematization in the context of the criteria set forth in Table 3 was held. The list of practices and indication of their criteria respective the values of the selection are 
presented in Table 4. We should note that the list of HRpractices must be constantly updated and supplemented

Table 3 Criteria for personnel training selection.

\begin{tabular}{|l|l|l|l|}
\hline \multirow{2}{*}{ Criterion } & \multicolumn{3}{|c|}{ Assessment } \\
\cline { 2 - 4 } & \multicolumn{1}{|c|}{1} & \multicolumn{1}{|c|}{2} & \multicolumn{1}{c|}{3} \\
\hline A. Price & $\begin{array}{l}\text { Low } \\
(0-10 \text { th.rub. })\end{array}$ & $\begin{array}{l}\text { Medium } \\
(10-50 \\
\text { th.rub. })\end{array}$ & $\begin{array}{l}\text { High } \\
\text { (more than 50 } \\
\text { th.rub. })\end{array}$ \\
\hline B. Duration & $\begin{array}{l}\text { Short-term } \\
(1-7 \text { days })\end{array}$ & $\begin{array}{l}\text { Medium-term } \\
(1 \text { week }-3 \\
\text { month })\end{array}$ & $\begin{array}{l}\text { Long-term } \\
\text { (more than 3 } \\
\text { month) }\end{array}$ \\
\hline C. Practicality & Theoretical & Mixed & Practical \\
\hline $\begin{array}{l}\text { D. } \\
\text { Professionalism }\end{array}$ & Inter-individual & Mixed & Professional \\
\hline E. Complexity & $\begin{array}{l}\text { Highly } \\
\text { specialized }\end{array}$ & $\begin{array}{l}\text { Number of } \\
\text { specializations }\end{array}$ & Complex \\
\hline $\begin{array}{l}\text { F. Number of } \\
\text { students }\end{array}$ & Individual & $\begin{array}{l}\text { Group } \\
(2-20 \\
\text { people) }\end{array}$ & $\begin{array}{l}\text { Mass } \\
\text { (more than 20 } \\
\text { people) }\end{array}$ \\
\hline
\end{tabular}

Table 4 Characteristics of training methods (fragment).

\begin{tabular}{|c|c|c|}
\hline № & Method & Criteria values \\
\hline 1. & Instructing & A.1; B.1; C. $3 ;$ D. $3 ;$ E.1; F.1 \\
\hline 2. & Rotation & A.1; B.2; C.3; D.2; E.2; F.1 \\
\hline 3. & Mentoring & A.1; B.2; C.2; D.2; E.3; F.1 \\
\hline 4. & Method of coping & A.1; B.1; C.3; D.3; E.1; F.1 \\
\hline 5. & Delegation method & A.1; В.2; C.2; D.2; E.3; F.1 \\
\hline 6. & Education by action & A.1; B.2; C.3; D.2; E.2; F.2 \\
\hline 7. & $\begin{array}{l}\text { Analysis of practical } \\
\text { situations }\end{array}$ & A.1; B.1; C.2; D.3; E.3; F.2 \\
\hline 8. & Training & A.2; B.1; C.3; D.2; E.3; F.2 \\
\hline 9. & Group discussion & A.1; B.1; C.2; D.2; E.3; F.2 \\
\hline 10. & Business and role games & A.1; B.1; C.2; D.2; E.3; F.2 \\
\hline 11. & Thematic seminars & A.2; B.1; C.2; D.3; E.1; F.2 \\
\hline 12. & Basket-method & A.1; B.1; C.3; D.3; E.2; F.1 \\
\hline 13. & Behavior modeling & A.1; B.1; C.2; D.2; E.3; F.2 \\
\hline 14. & Benchmarking & A.1; B.2; C.3; D.3; E.3; F.2 \\
\hline 15. & Coaching & A.2; B.2; C.2; D.2; E.3; F.1 \\
\hline 16. & E-learning & А. $2 ;$ В.2; С. $2 ;$ D. $3 ;$ Е. $3 ;$ F. 2 \\
\hline
\end{tabular}

To select the method of competence we apply the following scheme:

- Preliminary selection of the methods, taking into account their compliance with the content of the identified need for competence development is carried out. This correspondence is determined by the criterion of efficiency, unifying significant method characteristics such as, a practicality, professionalism and complexity $(\mathrm{Ri}=\mathrm{f}\{\mathrm{Ci}, \mathrm{Di}, \mathrm{El}\})$;
-Elaboration of the selection is carried by taking into consideration criteria price (Ai) and duration (Bi) of training. The most preferred method is to achieve a minimum amount of points according to the criteria (Table 5). In our case to the competence of the "knowledge market" is a method of analysis of practical situations, for competence "knowledge of technical and design features of enterprise's production "- instruction followed by observation and copying the experience of more experienced colleagues, and improvement of the company's goals and values understanding will contribute to training with and the group discussion.

Table 5 Recommendations for the training methods' selection.

\begin{tabular}{|l|l|l|l|l|l|}
\hline Competences & Effectiveness & Method & $\begin{array}{l}\text { Price } \\
\text { (A) }\end{array}$ & $\begin{array}{l}\text { Duration } \\
\text { (B) }\end{array}$ & Sum \\
\hline $\begin{array}{l}\text { K3 - Knowledge of } \\
\text { market }\end{array}$ & C.2; D.3; E.3 & M7 & 1 & 1 & 2 \\
\cline { 3 - 6 } & & M13 & 1 & 2 & 3 \\
\cline { 3 - 6 } & $\ldots$ & & & \\
\hline $\begin{array}{l}\text { K9 - Knowledge of } \\
\text { technical and design } \\
\text { features of } \\
\text { enterprise's } \\
\text { production }\end{array}$ & C.3; D.3; E.1 & M1 & 1 & 1 & 2 \\
\cline { 3 - 6 } $\begin{array}{l}\text { K13 - } \\
\text { Understanding of } \\
\text { the company's } \\
\text { values }\end{array}$ & C.3; D.2; E.3 & M4 & 1 & 1 & 2 \\
\cline { 3 - 6 } & & M5 & 1 & 2 & 3 \\
\cline { 3 - 6 } & M8 & 1 & 1 & 2 \\
\cline { 3 - 6 } & M9 & 1 & 1 & 2 \\
\cline { 3 - 6 } & M15 & 2 & 1 & 3 \\
\hline
\end{tabular}

Formed software for the whole enterprise has been focused on the maximum possible retention of employees, but the set of measures in the area of social security after the simulation has been somewhat curtailed due to a disproportionate growth in costs and benefits.

\section{Conclusion}

Any program of human resource development (HRD program) must meet the following general requirements:

- Be focused on the implementation of the organization's strategy, integrated with all aspects of its activities: research and development, manufacturing, sales and service, as well as be formed with taking into account not only internal but also external stakeholders of the organization;

- Assessed according to the impact of the key performance indicators of the organization, both operational (productivity, product quality) and financial (income, cost of business, market share);

- Integrate HR-practices of different groups: recruitment and selection of personnel, results-oriented assessment of personnel, training and development, the formation of the involvement and commitment of employees as well as their flexibility, readiness for change and the creation of new knowledge. 
What is more, while respecting the general principles, it must be differentiated, it must take into account both internal and external features of a particular organization activities.

The development of such a program requires the use of different methods and technologies: benchmarking, expert estimation, regression analysis, etc. It is useful to have a broader application in the field of cognitive and simulation because of the indirect effects of HRpractices on the results of the organization, as well as existing among various human resource management aspects of the relationship. This approach will allow to assess quantitatively the impact of HR-practices on organizational performance at the design stage of the human resource development program of while providing the option to account for a wide range of "situational" factors for a particular organization.

\section{Perspectives of the research}

It is most common today to the release three components in the structure of the organization's intellectual capital o: human, organizational and client capital [9]. At the crossroads of these three components the so-called organizational competence, considered today by an increasing number of theoreticians and practitioners as a basis for long-term development strategy of the organization are formed $[2,3,6,25]$. The most cited research in the field is the study of Hamel G., Prahalad C.K. (1990) [17], according to which the organizational competence is a set of skills and technologies that enables the company to provide its customers with significant benefits. In the course of its development, organizational competencies are converted into the key ones, the main properties of which are [17]:

- Ability to bring significant benefits in terms of the consumer;

- Being difficult to be copied, and what is even better - not to succumb to the simulation;

- Give potential access to a wide range of markets.

It is obvious that the source of organizational competencies are individual competencies of employees, not only professional but also personal. However, in the same way as in the model of the relationship between human resource management and performance (Figure 1) [14], this connection is not obvious, often it is untraceable, and therefore uncontrollable.

\section{References}

1. T.A. Gileva, Management in Russia and abroad, 5, 108-116 (2008)

2. T.A. Gileva, Scientific and technical sheets of the St. Petersburg Polytechnic University, 2, 166-171 (2008)

3. L.A. Ismagilov, T.A. Gileva, L.V. Sitnikova, Problems of the theory and practice of management, 9, 62-71 (2015)

4. D. Katalevsky, Fundamentals of simulation modeling and systems analysis in management (Publishing House Delo RANHiGS, Moscow, 2015)

5. T.N. Klemina, Russian Management Journal, 6, 3, 51-58 (2008)

6. B. Slavin, V. Soloviev, Problems of the theory and practice of management, 9, 72-78 (2015)
7. Y. Fitzents, Staff investment profitability: measurement of the economic value of personnel (Publishing house "Peak", Moscow, 2006)

8. R.M. Nizhegorodtseva, S.D. Reznik, Human capital theory and practice of management in the socioeconomic systems (Moscow, INFRA-M, 2015)

9. L. Edvinsson, Corporate longitude. Navigation in the economy based on knowledge (INFRA-M, Moscow, 2005)

10. A.G. Efendiyev, E.S. Balabanov, A.V. Rebrov, Russian Management Journal, 12, 1, 39-68 (2014)

11. M. Alagaraja, Human Resource Development Review, 12(2), 117-143 (2012)

12. M. Armstrong, Strategic Human Resource Management: A Guide to Action (Kogan Page, London, 2006)

13. B. Becker, M. Huselid, Journal of Management, 32(6), 898-925 (2006)

14. P. Boselie, G. Dietz, C. Boon, Human Resource Management Journal, 15(3), 67-94 (2005)

15. C.J. Collins, K.D. Clark, The Academy of Management Journal, 46(6), 740-751 (2003)

16. T. Garavan, R. Carbery, A Framework. Human Resource Development Review, 6(4), 394-418 (2007)

17. G. Hamel, C.K. Prahalad, Harvard Business Review, 5/6 (1990). http://www.enterrasolutions.com/media/docs /2013/08/Prahalad_Hamel_1990.pdf

18. E. Holton, B. Yamkovenko, Human Resource Development Review, 7(3), 270-291 (2008)

19. Human Resources Management and Training. Compilation of Good Practices in Statistical Offices. United Nations (New York and Geneva, 2013)

20. M. Huselid, Academy of Management Journal, 38(3), 635-672 (1995)

21. D. Mankin, Human Resource Development (Oxford University Press 2009)

22. J. Paauwe, Journal of Management Studies, 46(1), 129-142 (2009).

23. A. Paul, R. Anatharaman, International Journal of Human Resource Management, 14(7), 1246-1266 (2003).

24. R. Sanchez, Knowledge management and Organizational Competence (Oxford University Press, Oxford, 2003)

25. R. Schuler, S. Jackson, Academy of Management Executive, 1(3), 207-219 (1987)

26. R. Schuler, S. Jackson, Journal of Organizational Effectiveness: People and Performance, 1(1), 35-55 (2014)

27. J.M. Werner, R.L. DeSimone, Human Resource Development (South-Western, Cengage Learning, 2012) 